Rara! 
The publisher gratefully acknowledges the generous contribution to this book provided by the General Endowment Fund of the Associates of the University of California Press. 
Elizabeth McAlister Rara!

Vodou, Power, and

Performance in Haiti

and Its Diaspora

University of California Press

Berkeley Los Angeles London 
University of California Press

Berkeley and Los Angeles, California

University of California Press, Ltd.

London, England

(C) 2002 by the Regents of the University of California

Grateful acknowledgment is made for permission to reuse material from the author's essay " 'The Jew' in the Haitian Imagination: Premodern Anti-Judaism in the Postmodern Caribbean," in Black Zion: African American Religious Encounters with Judaism, edited by Yvonne Chireau and Nathaniel Deutsch, copyright (C) 2000 by Oxford University Press, Inc. Used by permission of Oxford University Press, Inc.

Thanks also for use of the following CD recordings:

"Notre Dame de 7 Douleurs," "Cemetery at Bizoton," and "Carrefour de Fort" ["Kalfou"] from the recording entitled Caribbean Revels: Haitian Rara and Dominican Gaga, Smithsonian Folkways 40402, provided courtesy of Smithsonian Folkways Recordings. (C) I991. Used by Permission.

"Grosè Bagay sa, Mwen Pa Kapab Ankò" and "Guantanamo M'Rive” from the recording entitled Rhythms of Rapture: Sacred Musics of Haitian Vodou, Smithsonian Folkways 40464, provided courtesy of Smithsonian Folkways Recordings. (C) I995. Used by Permission.

Library of Congress Cataloging-in-Publication Data

McAlister, Elizabeth A.

Rara! : vodou, power, and performance in Haiti and its diaspora / Elizabeth McAlister. p. $\mathrm{cm}$.

Includes bibliographical references, discography, and index.

ISBN 0-520-22822-7 (cloth : alk. paper)-ISBN 0-520-22823-5 (paper : alk. paper)

I. Rara Festival-Songs and music-History and criticism. 2. Voodoo music-HaitiHistory and criticism. 3. Folk music-Haiti-History and criticism. 4. Folk songs, CreoleHaiti-History and criticism. 5. Haiti-Social life and customs-2oth century. 6. HaitiSocial conditions-I97I- . I. Title.

$\mathrm{ML}_{3565} \cdot \mathrm{M}_{3} 842002$

394.265'96897294-dc2I 20010050I6

Manufactured in the United States of America

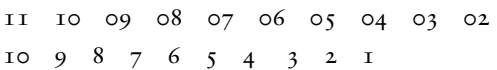

The paper used in this publication meets the minimum requirements of ANSI/NISO Z39.48-I 992 (R I997) (Permanence of Paper). 
For Lovely and Julien. This is where Mama was dancing, getting ready for yоu.

And for Phenel, wherever you are. You saved me in the streets of Port-auPrince. I wish I could have saved you from the streets of East Saint Louis. 
This page intentionally left blank 
To get anywhere in life you have to follow a road. . . . To make anything happen, you have to walk through the crossroads.

\section{Moris Moriset,}

president of Rara Ti-Malis Kache 
This page intentionally left blank 